\title{
Inventory of Praying Mantis (Mantodea) in Serdang Menang Village, Sirah Pulau Padang Sub-district, Ogan Komering Ilir District
}

\author{
Ari Sugiarto \\ Biologist at Serdang Menang Village, Sirah Pulau Padang Sub-district, Ogan Komering Ilir \\ District \\ Email: sugiartoari13@gmail.com
}

\begin{abstract}
Praying mantis included in the Mantodea order have good adaptations with camouflage and mimicry. The existence of a praying mantis in an ecosystem can help in controlling dangerous insect populations. Serdang Menang Village, Sirah Pulau Padang Sub-district, Ogan Komering Ilir District has various types of ecosystems such as plantation ecosystems, rice fields, settlements, and rivers. Need to do an inventory of praying mantis to complete data on fauna in Indonesia. This research was conducted in Serdang Menang Village in October 2018 by collecting samples of praying mantis around the green ecosystem. The results of the study only obtained 1 species of praying mantis, namely Heirodula formosana. Heirodula formosana which is found is green and some are brown. It can be concluded that variety of praying mantis in Serdang Menang Village is low.
\end{abstract}

Keywords: Praying Mantis, Serdang Menang Village

\section{Introduction}

Praying mantis included in the Mantodea order has good adaptation with camouflage and mimicry. This praying mantis also acts as a predator for grasshoppers, moths, butterflies, flies and aphids in the ecosystem (Sureshan and Sambath, 2009). According to Prokop and Radovan (2008), praying mantis has cannibalism behavior at the time of marriage. Based on Prokop and Radovan's research, it was found that female mantis life affects cannibalism behavior when mating.

The spread of praying mantis is spread throughout the world with diverse abundance and diversity. The greater abundance and diversity of praying mantis is found in the tropics and macronesia (Torres, 2015). The number of species of praying mantis is estimated at more than 2,300 species (Zhang and Fei, 2017) out of a total of 15 families namely Mantoididae, Chaeteessidae, Metallyticidae, Amorphoscelidae, Eremiaphilidae, Acanthopidae,
Hymenopodidae, Liturgusidae, Tarachodidae, Thespidae, Iridopterygidae, Mantidae, Toxoderidae, Sibyllidae and Empusidae (Weiland, 2010).

Identification of species of praying mantis can be done by analyzing morphological characters such as those carried out by Weiland (2010) whose identified 122 species of mantis grasshopper from 15 families by encoding 152 morphological characters of the praying mantis. Such as eye distance, pronotum length, pronotum width, front femur length, front femur width, rear femur length, rear femur width, and body length (Battiston el at., 2014).

Serdang Menang Village, Sirah Pulau Padang Sub-district, Ogan Komering Ilir District has various types of ecosystems such as plantation ecosystems, rice fields, settlements, and rivers that support species diversity. Data on species of praying mantis in Serdang Menang Village is not yet available. It is necessary to carry out an 
inventory of the praying mantis in Serdang Menang Village, Sirah Pulau Padang Subdistrict, Ogan Komering Ilir District to complete the existing fauna data in Indonesia.

\section{Research Metods}

This the research was carried out in Serdang Menang village, Sirah Pulau Padang Sub-district, Ogan Komering Ilir District in October 2018. Collection of praying mantis samples was carried out around the green ecosystem area (plantation ecosystems, rice fields, and riverside). Samples were taken using insecting net and took pictures of praying mantis with camera (Patel et al., 2018). Samples are searched by sweeping area at a predetermined location (Dwari and Amal, 2018). Identification species of praying mantis that was found was carried out by matching the identified spotted photos.

\section{Result and Disscusion}

Based on the research that has been done, obtained species of praying mantis in Serdang Menang Village, Sirah Pulau Padang Sub-district, Ogan Komering Ilir District namely:

Table 1. Species of praying mantis in Serdang Menang Village, Sirah Pulau Padang Subdistrict, Ogan Komering Ilir District

\begin{tabular}{cccc}
\hline Family & Species & Pictures \\
\hline Mantidae & Heirodula formosana & & \\
& & $($ Green) & (Brown) \\
\hline
\end{tabular}

Species of praying mantis found in Serdang Menang Village, Sirah Pulau Padang Sub-district, Ogan Komering Ilir District, namely Heirodula formosana from the Mantidae family. Species of praying mantis that is found is green and brown. This praying mantis is found in the lower vegetation of the plantation and rice field ecosystem.

Based on the results of the research by Dwari and Amal (2018), praying mantis from the Mantidae family is the most widely found. Based on the research by Patel et al. (2018), praying mantis from the Heirodula genus has a high abundance. Based on genetic analysis, Heirodula formosana is closely related to Rhombodera valida (Zhang and Fei, 2017). But the research by Weiland (2010),
Heirodula and Rhombodera are one similarity based on morphological characteristics.

The existence of praying mantis on rice field and plantation ecosystem can certainly be an advantage. According to Sureshan and Sambath, (2009), praying mantis is a predator for grasshoppers, moths, butterflies, flies and aphids. According to Dwari and Amal (2018), the existence of praying mantis on rice field and plantation ecosystems can help in controlling dangerous insect populations.

\section{Conclucion}

Based on the research that has been carried out in Serdang Menang Village, Sirah Pulau Padang Sub-district, Ogan Komering Ilir Dsitrict has the conclusion 
that the species of mantis that is found is only species of Heirodula formosana from the Mantidae family. Heirodula formosana found green and brown. The diversity of praying mantis in this location can be said to be low.

\section{Reference}

Battiston, R., Joaguin, O., Jose, R.C., and Pedro, J.C. 2014. A Revision of Apteromantis (Mantodea: Mantidae, Amelinae): A Comprehensive Approach to Manage Old Taxonomic and Conservation Problems. Zootaxa. 3797(1): 65-77.

Dwari, S and Amal, K.M. 2018. Diversity of mantids (Insecta: Mantodea) of Howrah District, West Bengal, India. Journal of Entomology and Zoology Studies. 6(2): 1038-1042.

Patel, H.N., A.G, Shukla, A.H, Patel, dan J.N, Prajapati. 2018. Mantids (Mantodea) of Navsari Agricultural University Campus (Gujarat): An Inventory. International Journal of Current Microbiology and Applied Sciences. 7(6): 3594-3599.

Prokov, P and Radovan, V. 2008. Seasonal Aspects of Sexual Cannibalism in the Praying Mantis (Mantis religiosa). J. Ethol. 26(1): 213-218.

Sureshan P.M and Sambath S. 2009. Mantid (Insecta: Mantodea) Fauna of Old Bihar (Bihar and Jharkhand) with Some New Records for the State. Records of the Zoological Survey of India. 109(3):11-26.

Torres, F.P. 2015. Clase Insecta: Orden Mantodea. Revista. 1-10.

Wiland, F. 2010. The Phylogenetic System of Mantodea (Insecta: Dictyoptera). Dissertation. zur Erlangung des Doktorgrades der Mathematisch-
Naturwissenschaftlichen Fakultäten der Georg-August-Universität zu Göttingen.

Zhang, H.L and Fei, Y. 2017. Comparative Mitogenomic Analyses of Praying Mantises (Dictyoptera, Mantodea): Origin and Evolution of Unusual Intergenic Gaps. International Journal of Biological Sciences. 13(3): 367-382. 